\title{
Risk factors and management of ectopic pregnancy
}

\author{
Shradha S. Maka ${ }^{1 *}$, Sangamesh B. Tondare ${ }^{2}$, Mahesh B. Tondare ${ }^{3}$
}

${ }^{1}$ Department of Obstetrics and Gynecology, MRMC, Kalaburagi, Karnataka, India

${ }^{2}$ Department of Surgery, GIMS, Kalaburagi, Karnataka, India

${ }^{3}$ Community Medicine Department, BRIMS, Bidar, Karnataka, India

Received: 03 July 2017

Revised: 24 July 2017

Accepted: 31 July 2017

*Correspondence:

Dr. Shradha S. Maka,

E-mail: shradhasmaka@gmail.com

Copyright: (c) the author(s), publisher and licensee Medip Academy. This is an open-access article distributed under the terms of the Creative Commons Attribution Non-Commercial License, which permits unrestricted non-commercial use, distribution, and reproduction in any medium, provided the original work is properly cited.

\section{ABSTRACT}

Background: One of the critical and commonest acute abdominal emergencies which a gynaecologist has to manage in day to day practise is ectopic pregnancy. The present study is compilation to know the risk factors and different modalities of medical and surgical management of patients with ectopic pregnancy.

Methods: All patients diagnosed of Ectopic pregnancy at Basaveshwar teaching and general hospital and Sangameshwar teaching and general hospital attached to Mahadevappa Rampure Medical College were part of the study, over a period of two years (August 2014 to July 2016). It was a prospective study with pivot tables, graphs and chi square test.

Results: In a span of 2 years 50 cases were studied. Maximum age incidence was 21-25 years. Greater incidence was seen in primigravida accounting for $28 \%$. Most patients presented with pain in abdomen (50 cases). Risk factors included previous abortion, contraception history, sterilization history and pelvic surgery. 47 cases underwent laparotomy and 3 cases were managed medically. $66 \%$ had tubal rupture and the most common site was ampulla. Post-operative period was uneventful in majority of cases.

Conclusions: With the increasing incidence of ectopic pregnancy, screening of high risk cases, early diagnosis and early intervention are required to prevent the maternal deaths and conservation of reproductive health.

Keywords: Ectopic pregnancy, Maternal deaths, Salphingectomy

\section{INTRODUCTION}

One of the critical and commonest acute abdominal emergencies which a gynaecologist has to manage in day to day practise is "Ectopic pregnancy". It is a threat to the life of a women and her future fertility which causes mutilation of organs of reproduction. Ectopic pregnancy is a disease of diagnostic surprise as described by Novak, the physician who has ectopic on the brain rarely fails to make the diagnosis when it exists and he will diagnose it often when it's not present.
The term ectopic is comprehensive than extra uterine or tubal pregnancy for it includes all varieties of gestation outside the uterine cavity.

The word ectopic is from Greek; 'EX' and 'TOPOS' meaning "out of place". Following fertilization and fallopian tube transit, the blastocyst normally implants in the endometrial lining of the uterine cavity. Implantation elsewhere is considered ectopic pregnancy. ${ }^{1}$ This implantation at an aberrant site is inconducive to growth and development of blastocyst. 
It includes all gestations implanted in

- Fallopian tube

- Ovarian pregnancy

- Cervical pregnancy

- Abdominal pregnancy

- Cesarean scar pregnancy.

- Distant sites.

The occurrence of ectopic has been increasing at an alarming rate because of increase in infertility, IVF and sexually transmitted diseases. Different diagnostic modalities continue to evolve for ectopic pregnancy. Application of serial human chorionic gonadotropin beta subunit measurements in combination with ultrasonography has facilitated identification of ectopic pregnancies. Treatment of ectopic pregnancy has evolved from laparotomy to laparoscopy.

The objectives of present study were to study the risk factors associated with ectopic pregnancy and to study the different modalities of medical and surgical management of patients with ectopic pregnancy depending on clinical presentation.

\section{METHODS}

Patients presenting with symptoms suggestive of ectopic pregnancy and found to have ectopic pregnancy on investigations were enrolled in this study after informed consent at Basaveshwar and Sangameshwar teaching and general hospitals attached to Mahadevappa Rampure Medical College, Kalaburgi.

\section{Inclusion criteria}

All diagnosed cases of ectopic pregnancy.

\section{Exclusion criteria}

Intrauterine pregnancies.

All patients with a history of amenorrhea, with history of pain abdomen, per vaginal bleeding, syncope, symptoms and signs of shock, detailed history including age group, parity, risk factors like, use of contraception, any history of infertility and any treatment for the same, history of abortions, details of any pelvic infections, history of tubal sterilization, smoking and previous history of ectopic pregnancy will be taken.

Clinical examination (per abdomen and pelvic examination) will be done. Apart from routine investigations special investigations that will be done include, UPT, ultrasound scan (transabdominal and/or transvaginal), $\beta$ hCG measurement, culdocentesis will be done. The details of the management will be recorded including surgical procedure and intra operative findings. Patient will be followed up till the duration of hospital stay for immediate postoperative complications and recovery.

\section{Statistical analysis}

Frequencies charting and Chi Square statistical methods were employed in the present study.

\section{RESULTS}

50 cases were collected from Basveshwar and Sangameshwar teaching and general hospital attached to Mahadevappa Rampure Medical College, Kalaburagi carried out for two years from August 2014 to July 2016.

Table 1: Ectopic pregnancy in relation to age.

\begin{tabular}{|lll|}
\hline Age (years) & Frequency & $\%$ \\
\hline$<20$ & 4 & 8.0 \\
\hline $21-25$ & 21 & 42.0 \\
\hline $26-30$ & 17 & 34.0 \\
\hline $31-35$ & 8 & 16.0 \\
\hline Total & 50 & 100.0 \\
\hline
\end{tabular}

In this study, maximum patients were in the age group of 21-25 years ( $42 \%)$, followed by $26-30$ years $(34 \%)$.

Table 2: Distribution of cases based on gravida.

\begin{tabular}{|lll|}
\hline Gravida & No. of cases & $\%$ \\
\hline G1 & 14 & 28 \\
\hline G2 & 13 & 26 \\
\hline G3 & 13 & 26 \\
\hline G4 & 9 & 18 \\
\hline G6 & 1 & 2 \\
\hline Total & 50 & 100 \\
\hline
\end{tabular}

In this study, maximum patients were primigravida (28\%), followed by gravida 2 and $3(26 \%)$.

Table 3: Distribution of cases based on clinical presentation in ectopic pregnancy distribution depending on symptoms.

\begin{tabular}{|lll|}
\hline Symptoms & No. of cases & $\%$ \\
\hline Abdominal pain & 50 & 100 \\
\hline Amenorrhea & 49 & 98 \\
\hline Bleeding & 20 & 40 \\
\hline
\end{tabular}

Abdominal pain was commonest symptom and present in 50 cases $(100 \%)$, amenorrhea was present in 49 cases $(98 \%)$, bleeding per vagina was present in 20 cases $(40 \%)$.

In the present study 25 cases had risk factors. 11 cases had history of abortion, 5 cases had history of contraceptive use, 4 cases had conceived after infertility treatment, 2 cases had history of sterilization, pelvic surgery was done in 2 cases, 1 case had PID. 
Table 4: Distribution of cases based on risk factors for ectopic pregnancy.

\begin{tabular}{|lll|}
\hline Risk factors & No. of cases & $\%$ \\
\hline $\begin{array}{l}\text { Conceived after infertility } \\
\text { treatment }\end{array}$ & 4 & 16 \\
\hline Contraception failure & 5 & 20 \\
\hline Post Sterilization & 2 & 8 \\
\hline MTP (Dand C) & 11 & 44 \\
\hline Pelvic surgery & 2 & 8 \\
\hline Pelvic inflammatory disease & 1 & 4 \\
\hline Total & 25 & 100 \\
\hline
\end{tabular}

Table 5: Distribution of cases based on risk factors for ectopic pregnancy in detail.

\begin{tabular}{|lll|}
\hline Risk factors & No. of cases & $\%$ \\
\hline Conceived after infertility treatment & 4 & - \\
\hline Concieved after ICSI & 1 & 4 \\
\hline Ovulation induction & 3 & 12 \\
\hline MTP & 11 & 44 \\
\hline Contraception failure & 5 & - \\
\hline IUCD & 3 & 12 \\
\hline Depoprovera & 1 & 4 \\
\hline Progesterone only pill & 1 & 4 \\
\hline Post sterilization & 2 & - \\
\hline Tubectomy & 1 & 4 \\
\hline Lap tubectomy & 1 & 4 \\
\hline Pelvic inflammatory disease & 1 & 4 \\
\hline Pelvic surgery & 2 & - \\
\hline Lap surgery for ovarian cyst & 1 & 4 \\
\hline RT oophorectomy, appendicectomy & 1 & 4 \\
\hline Total & 25 & 100 \\
\hline
\end{tabular}

In this study 11 cases had history of previous abortion, 4 cases had history of infertility and treated for the same in form of ovulation induction and ICSI (intracytoplasmic sperm injection), 2 cases with failed sterilization (tubectomy and lap tubectomy), 3 cases with IUCD insertion, 2 cases with previous surgery, 2 cases with hormonal contraceptive use, 1 case with PID, 25 cases had no risk factor. Few cases had more than one risk factor.

Table 6: Management of ectopic pregnancy.

\begin{tabular}{|lll|}
\hline Procedure & $\begin{array}{l}\text { No. of } \\
\text { cases }\end{array}$ & $\%$ \\
\hline Medical & 3 & 6 \\
\hline Surgical & 47 & 94 \\
\hline Unilateral salphingectomy-Left & 11 & 22 \\
\hline Unilateral salphingectomy-Right & 21 & 42 \\
\hline Bilateral salphingectomy & 4 & 8 \\
\hline Right salphingectomy+left tubectomy & 4 & 8 \\
\hline Left salphingectomy+right tubectomy & 3 & 6 \\
\hline Left salphingo- oophorectomy & 1 & 2 \\
\hline Right salphingo-oophorectomy & 1 & 2 \\
\hline Left horn resection & 1 & 2 \\
\hline Right horn repair & 1 & 2 \\
\hline Total & 50 & 100 \\
\hline
\end{tabular}

Most cases had unilateral salphingectomy (32 cases), 4 cases underwent bilateral salphingectomy, 7 cases underwent Ipsilateral salphigectomy with contralateral tubectomy, 2 cases had salphingooophorectomy, 1 had horn resection, 1 had repair of horn, 3 were treated medically. Both medically treated patients lost to follow up.

Table 7: Site of ectopic pregnancy on laparotomy.

\begin{tabular}{|c|c|c|}
\hline Site & No. of cases & $\%$ \\
\hline Ampulla & 18 & 38 \\
\hline Infundibulum & 11 & 24 \\
\hline Isthmus & 9 & 19 \\
\hline Cornua/interstitial & 7 & 15 \\
\hline Left horn & 1 & 2 \\
\hline Right horn & 1 & 2 \\
\hline Total & 47 & 100 \\
\hline
\end{tabular}

In this study, more cases were ampullary pregnancy 18 cases $(38 \%)$, followed by Infundibulum 11 cases $(23 \%)$, followed by cornual/interstitial 7 cases (15\%) and isthmus 9 cases $(19 \%)$.

\section{DISCUSSION}

In this study, maximum patients were in the age group of 21-25 years followed by $26-30$ years. $16 \%$ were in the age group 31-35 years, similar to Sanjay $\mathrm{P}$ et al $47.5 \%$ in 21-25 age group. ${ }^{2}$

Table 8: Age pattern in ectopic pregnancy.

\begin{tabular}{|llll|}
\hline $\begin{array}{l}\text { Age distribution } \\
\text { (years) }\end{array}$ & $\begin{array}{l}\text { Present } \\
\text { study }\end{array}$ & $\begin{array}{l}\text { Porwal } \\
\text { et al }\end{array}$ & $\begin{array}{l}\text { Samiya } \\
\text { et al }\end{array}$ \\
\hline$<20$ & $8 \%$ & $5 \%$ & - \\
\hline $21-25$ & $42 \%$ & $47.5 \%$ & $20 \%$ \\
\hline $26-30$ & $34 \%$ & $25 \%$ & $55 \%$ \\
\hline $31-35$ & $16 \%$ & $22.5 \%$ & $16 \%$ \\
\hline $36-40$ & - & - & $6 \%$ \\
\hline$>40$ & - & - & $2 \%$ \\
\hline
\end{tabular}

Samiya et al found maximum age group of 26-30 years. ${ }^{3}$ In the studies of centre for disease control maximum number of women was in the age group of 35-40 years.

Table 9: Gravida pattern in ectopic pregnancy.

\begin{tabular}{|lll|l|}
\hline Gravida & Present study & Porwal et al & Samiya et al \\
\hline G1 & $28 \%$ & $40 \%$ & $53 \%$ \\
\hline G2 & $26 \%$ & $20 \%$ & $29 \%$ \\
\hline G3 & $26 \%$ & $31.5 \%$ & $10 \%$ \\
\hline G4 & $18 \%$ & $7.5 \%$ & $3.5 \%$ \\
\hline G6 & $2 \%$ & - & $2.63 \%$ \\
\hline
\end{tabular}

In this study, maximum patients were Primigravida (28\%) followed by gravida 2 and 3(26\%). There were $18 \%$ of gravida 4. Similarly, Porwalet al and Samiya et al studies primigravida were $40 \%$ and $53 \%$ respectively., ${ }^{2,3}$ According to ICMR multicentric case control study 
(1990) of ectopic pregnancy, majority of women were young and had low parity. ${ }^{4}$ Precise estimation of the true incidence of ectopic pregnancy is difficult, but the most recent estimate by the $\mathrm{CDC}$ is $2 \%$ of reported pregnancies. $^{5}$

Table 10: Clinical presentation of ectopic pregnancy.

\begin{tabular}{|llll|}
\hline $\begin{array}{l}\text { Clinical } \\
\text { presentation }\end{array}$ & $\begin{array}{l}\text { Present } \\
\text { study }\end{array}$ & Rashmi & $\begin{array}{l}\text { Shetty } \\
\text { K et al }\end{array}$ \\
\hline Pain abdomen & $100 \%$ & $89.2 \%$ & $80.6 \%$ \\
\hline Amenorrhea & $98 \%$ & $75.7 \%$ & $77.4 \%$ \\
\hline Bleeding per vagina & $40 \%$ & $43.2 \%$ & $61.3 \%$ \\
\hline Fornices tenderness & $92 \%$ & $70.3 \%$ & $48.4 \%$ \\
\hline Cervical tenderness & $86 \%$ & 75.7 & $51.6 \%$ \\
\hline
\end{tabular}

Abdominal pain was the commonest symptom and present in $100 \%$, followed by amenorrhea in $98 \%$, per vaginal bleeding in $40 \%$. This is similar to study of Rashmi AG and Shraddha Shetty $\mathrm{K}$ et al in which majority of the cases presented with pain in the abdomen (89.2\% of cases and $80.6 \%$ cases resp), amenorrhoea $(75.7 \%$ and $77.4 \%)$ and spotting $(43.2 \%$ and $61.3 \%)$ respectively. ${ }^{6,7}$ In present study, cervical motion tenderness was seen in $86 \%$ and fornix tenderness in $92 \%$.

Table 11: Risk factors in ectopic pregnancy.

\begin{tabular}{|lllll|}
\hline Risk factors & Present & $\begin{array}{l}\text { Samiya } \\
\text { et al }\end{array}$ & $\begin{array}{l}\text { Shetty } \\
\text { K et al }\end{array}$ & $\begin{array}{l}\text { Porwal } \\
\text { et al }\end{array}$ \\
\hline $\begin{array}{l}\text { Infertility } \\
\text { treated }\end{array}$ & $8 \%$ & $8.77 \%$ & $3.2 \%$ & $22.5 \%$ \\
\hline $\begin{array}{l}\text { Previous } \\
\text { ectopic }\end{array}$ & - & $5.2 \%$ & $3.2 \%$ & $5 \%$ \\
\hline Tubal surgery & $4 \%$ & - & $3.2 \%$ & $10 \%$ \\
\hline IUCD & $6 \%$ & - & $6.4 \%$ & $5 \%$ \\
\hline D and C & $22 \%$ & $21.05 \%$ & $29 \%$ & - \\
\hline $\begin{array}{l}\text { Pelvic surgery } \\
\text { PID (pelvic }\end{array}$ & $4 \%$ & $10.5 \%$ & - & - \\
\hline $\begin{array}{l}\text { inflammatory } \\
\text { disease) }\end{array}$ & $2 \%$ & $10.01 \%$ & $3.2 \%$ & $47.5 \%$ \\
\hline
\end{tabular}

The most common risk factor was D and C (MTP) which was seen in $22 \%$ which is similar to Samiya et al study with $21.05 \%$ and $29 \%$ in Shetty SK et al. ${ }^{3,7}$ In present study $8 \%$ were infertility treated which is significantly more, similar to Sanjay P et al $22.5 \%$. $^{2}$ IUCD insertion history was seen in $6 \%$, tubal surgery and pelvic surgery in $4 \%$ cases. The most important risk factors for ectopic pregnancy are a history of tubal surgery, including tubal ligation, prior ectopic pregnancy, and history of pelvic inflammatory disease, intrauterine device (IUD) use, in utero diethylstilbestrol (DES) exposure, are associated with increased risk for ectopic gestation..$^{89}$

Up to half of women with ectopic pregnancy will have no identifiable risk factors. Many other risk factors, including smoking and multiple lifetime sexual partners, are weakly associated with ectopic pregnancy overall the percentage of ectopic pregnancies in sterilised women have reported to be 5-16\%. ${ }^{10-12}$ An increased incidence of ectopic pregnancy has been reported with use of progestin only contraceptives. ${ }^{13}$ Tubal pregnancy is increased following gamete intrafallopian transfer (GIFT) and In-vitro fertilization. ${ }^{14}$ Extratubal as well heterotopic tubal pregnancies are also increased after these procedures. ${ }^{15}$

Table 12: Site of ectopic pregnancy on laparotomy.

\begin{tabular}{|lllll|}
\hline $\begin{array}{l}\text { Site of } \\
\text { ectopic }\end{array}$ & Present & $\begin{array}{l}\text { Porwal } \\
\text { et al }\end{array}$ & $\begin{array}{l}\text { Shetty } \\
\text { K et al }\end{array}$ & $\begin{array}{l}\text { Rashmi } \\
\text { A }\end{array}$ \\
\hline Ampullary & $38 \%$ & $40 \%$ & $45.2 \%$ & $69.7 \%$ \\
\hline Isthmus & $15 \%$ & $32.5 \%$ & $6.5 \%$ & $3 \%$ \\
\hline Infundibular & $24 \%$ & $5 \%$ & $22.6 \%$ & - \\
\hline Interstitial & $15 \%$ & $12.5 \%$ & $19.4 \%$ & $15 \%$ \\
\hline Heterotrophic & $6 \%$ & - & $6.5 \%$ & - \\
\hline Ovarian & - & - & $6.5 \%$ & - \\
\hline
\end{tabular}

Ampullary pregnancy was most common site. In present study it is $38 \%$, similar to Sanjay P et al, Shraddha SK et al and Rashmi AG 40\%, 45.2\%, 69.7\% respectively. ${ }^{2,6,7}$ In present study infundibular pregnancy was seen in $24 \%$ cases, similar to Shraddha SK et al it was $22.6 \% .^{7}$ In present study isthmic and interstitial was $15 \%$, heterotrophic was seen in $10 \%$ cases. Incidence of heterotrophic pregnancy varies widely from 1 in 100 to 1 in 30,000 pregnancies. A high index of suspicion can help in timely diagnosis and appropriate intervention. ${ }^{16}$ The treatment of a heterotopic pregnancy is laparoscopy/laparotomy for the tubal pregnancy. ${ }^{17}$

Table 13: Condition of tube on laparotomy.

\begin{tabular}{|c|c|c|c|c|}
\hline $\begin{array}{l}\text { Condition } \\
\text { of tube }\end{array}$ & Present & $\begin{array}{l}\text { Samiya } \\
\text { et al }\end{array}$ & Rashmi & $\begin{array}{l}\text { Shetty K } \\
\text { et al }\end{array}$ \\
\hline Ruptured & $66 \%$ & $60.5 \%$ & $78.3 \%$ & $61.3 \%$ \\
\hline $\begin{array}{l}\text { Chronic } \\
\text { ectopic }\end{array}$ & $2 \%$ & $3.5 \%$ & - & - \\
\hline Unruptured & - & $35.08 \%$ & $8.1 \%$ & $22.5 \%$ \\
\hline $\begin{array}{l}\text { Tubal } \\
\text { abortion }\end{array}$ & $32 \%$ & - & - & $12.9 \%$ \\
\hline
\end{tabular}

In present study, tubal rupture was seen in $66 \%$, similar to Samiya et al, Rashmi AG and Shraddha SK et al in which it is $60.5 \%, 78.3 \%, 61.3 \%$ respectively. ${ }^{3,6,7}$ Chronic ectopic in present study was $2 \%$, in Samiya et al it was $3.5 \%$. $^{3}$ Tubal abortion in $32 \%$ cases, in Shraddha Shetty $\mathrm{K}$ et al it was $12.9 \%$. $^{7}$

Table 14: Management of ectopic pregnancy.

\begin{tabular}{|c|c|c|c|c|}
\hline Treatment & Present & $\begin{array}{l}\text { Porwal } \\
\text { et al }\end{array}$ & $\begin{array}{l}\text { Samiya } \\
\text { et al }\end{array}$ & $\begin{array}{l}\text { Shetty K } \\
\text { et al }\end{array}$ \\
\hline Methotrexate & $6 \%$ & - & $0.87 \%$ & - \\
\hline $\begin{array}{l}\text { Unilateral } \\
\text { salphingectomy }\end{array}$ & $78 \%$ & $45 \%$ & $65 \%$ & $90.3 \%$ \\
\hline $\begin{array}{l}\text { Bilateral } \\
\text { salphingectomy }\end{array}$ & $8 \%$ & $12.5 \%$ & $8 \%$ & - \\
\hline $\begin{array}{l}\text { Salphingo } \\
\text { oophorectomy }\end{array}$ & $4 \%$ & $32.5 \%$ & - & $6.5 \%$ \\
\hline
\end{tabular}


In present study majority of cases unilateral salphingectomy was done $78 \%$, similar to Porwal sanjay et al, Samiya et al and Shetty $\mathrm{S}$ et al it was $45 \%, 65 \%$, $90.3 \%$ respectively. ${ }^{2,3,7} 8 \%$ underwent bilateral salphingectomy, in Sanjay $\mathrm{P}$ et al and Samiya et al it was $12.5 \%$ and $8 \% .^{2,3}$ Systemic methotrexate is emerging as the standard medical regimen. ${ }^{18}$ Early diagnosis is critical with medical therapy. Before the advent of salpingectomy in 1884 , ectopic pregnancies were treated expectantly and carried a mortality rate of around $70 \% .{ }^{19}$ Ylostalo et al described selecting 127 (25\%) out of 507 ectopic pregnancies over 3 years for expectant management. ${ }^{20}$

\section{CONCLUSION}

There is an increase in the incidence of ectopic pregnancy and a decrease in maternal mortality due to ectopic pregnancy, during last two decades. The treatment modality also has evolved from radical to conservative surgery and even to medical and expectant management. But in present study maximum cases were managed surgically, as they were brought late with established diagnosis of ruptured ectopic pregnancy. It is therefore important that one should be sensitive to the fact that in reproductive age group any women presenting with pain in the lower abdomen, differential diagnosis should be ectopic pregnancy irrespective of presence or absence of amenorrhea, whether or not she has undergone sterilization. Early identifying of underlying risk factors, diagnosis with the essential aids like transvaginal ultrasound and $\beta$-hCG and timely intervention in the form of medical and surgical treatment will definitely help in reducing the morbidity and mortality and to improve reproductive outcome. This study was undertaken for a better understanding of ectopic gestation, its clinical presentation, risk factors and management. Urine pregnancy test was positive in $94 \%$ cases, culdocentesis was positive in $68 \%$. Unilateral salphingectomy was done in 32 cases $(64 \%)$. Haemoglobin on admission was $<7 \mathrm{~g}$ was seen in $44 \%$. $80 \%$ of the cases blood was transfused both intraoperative and postoperatively.

Funding: No funding sources Conflict of interest: None declared

Ethical approval: The study was approved by the Institutional Ethics Committee

\section{REFERENCES}

1. Cunningham FG, Leveno KJ, Bloom SL, Spong CY, Dashe JS, Hoffman BL et al. Williams obstetrics. $24^{\text {th }}$ ed. Mc Graw Hill Education. Chapter 19. 2014:377.

2. Gupta R, Porwal S, Swarnkar M, Sharma N, Maheshwari P. Incidence, trends and risk factors for ectopic pregnancies in a tertiary care hospital of Rajasthan. JPBMS. 2012;16(07).
3. Mufti S, Rather S, Mufti S, Rangrez RA, Wasiqa K. Ectopic pregnancy: an analysis of 114 cases. JK-Pract. 2012;17(4):20-3.

4. ICMR task force project 1990. Multicentric case control study of ectopic pregnancy. J Obstet Gynecol India. 1990;40:425-430.

5. Centers for Disease Control and Prevention (CDC. Ectopic pregnancy--United States, 1990-1992. MMWR. 1995;44(3):46.

6. Gaddagi RA, Chandrashekhar AP. A clinical study of ectopic pregnancy. J Clin Diag Res. 2012;6(5):867-9.

7. Shetty S, Shetty A. A clinical study of ectopic pregnancies in a tertiary care hospital of Mangalore India. Innov J Med Health Sci. 2014;4(1):305-9.

8. Murray H, Baakdah H, Bardell T, Tulandi T. Diagnosis and treatment of ectopic pregnancy. CMAJ. 2005;173:905-912.

9. Ankum WM, Mol BW, Van der Veen F, Bossuyt PM. Risk factors for ectopic pregnancy: a meta analysis. Fertil Steril. 1996;65:1093-9.

10. Buckley RG, King KJ, Disney JD, Gorman JD, Klausen $\mathrm{JH}$. History and physical examination to estimate risk of ectopic pregnancy: validation of a clinical prediction model. Ann Emerg Med. 1999;34(5):589-94.

11. Dart RG, Kaplan B,Varaklis K. Predictive value of history and physical examination in patients with suspected ectopic pregnancy. Ann Emerg Med. 1999;33:283-90.

12. Cheng MC, Wong YM, Rochat RW, Ratnam SS. Sterilisation failures in Singapore an examination of ligation techniques and failure rates. Stud Fam Plann. 1977;8:109-115.

13. Ory HW. Ectopic pregnancy and intrauterine contraceptive devices: new perspectives. The Women's Health Study. Obstet Gynecol. 1981;57(2):137-44.

14. Coste J, Job-Spira N, Fernandez H, Papiernik E, Spira A. Risk factors for ectopic pregnancy: a case-control study in France, with special focus on infectious factors. Am J Epidemiol. 1991;133(9):839-49.

15. Kendrick JS, Atrash HK, Strauss LT, Gargiullo PM, Ahn YW. Vaginal douching and the risk of ectopic pregnancy among black women. Am J Obstet Gynecol. 1997;176(5):991-7.

16. Govindarajan MJ, Rajan R. Heterotopic pregnancy in natural conception. J Hum Reprod Sci. 2008;1(1):37-8.

17. Ectopic Pregnancy. Text book of Williams Obstetrics. Multifetal Ectopic Pregnancy. $21^{\text {st }}$ ed. Chapter 34. 2003:888-9.

18. Stabile I, Grudzinkas JG. Ectopic pregnancy whats new? Progress Obstet Gynecol.1994:281-310

19. Parry JS. Extrauterine pregnancy: Its causes, species, pathologic anatomy, clinical history, diagnosis, prognosis, and treatment. Philadelphia, Lea and Febiger, zit. Leach RE, Ory SJ (1989) Modern management of ectopic pregnancy. J Reprod Med. 1876;34:324-38.

20. YlÖstalo P, Cacciatore B, SjÖberg J, KÄÄriÄinen M, Tenhunen A, Stenman UH. Expectant management of ectopic pregnancy. Obstet Gynecol. 1992;80:345-8.

Cite this article as: Maka SS, Tondare SB, Tondare MB. Risk factors and management of ectopic pregnancy. Int J Reprod Contracept Obstet Gynecol 2017;6:3776-80. 